\title{
Multi-functional Micro Machine Tool for Cell Manufacturing System
}

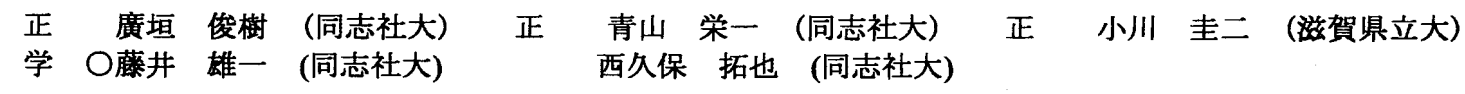

\section{1 粕 言}

変種変量生産を実現する生産方式であるセル生産システ ムに対応するために, マイクロ多機能工作機械が必要であ る.そこで, 本研究では, 切削機能と半導体レーザによる熱 処理機能を集約したデスクトップサイズの多機能工作機械 を試作した.これまで，著者らは，試作機の基本性能評価 をしてきた(1). しかし，半導体レーザによる小型ワークへ の焼入れ性の評価が不十分であった. そこで，本報では， 小型ワークとして薄板を用いて, 半導体レーザによる焼入 れ性を調べた。

\section{2 試作錐の概要およひ特徽}

試作機の外観を図 1 に示す．本機は主軸が 3 軸移動する タイプの NC 加工機（幅 $300 \times$ 奥行き $500 \times$ 高さ $400[\mathrm{~mm}]$ ） であり, 加工範囲は $50 \times 50 \times 50[\mathrm{~mm}]$, 機械重量は $66 \mathrm{~kg}$ である. レーザ熱処理機能としては, 定格出力 $50 \mathrm{~W}$, スポ ット径 $0.6 \mathrm{~mm}$, 波長 $808 \mathrm{~nm}$ の半導体レーザをレーザ熱源と して用いた.

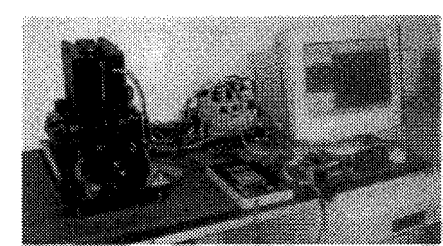

(a) Prototype machine

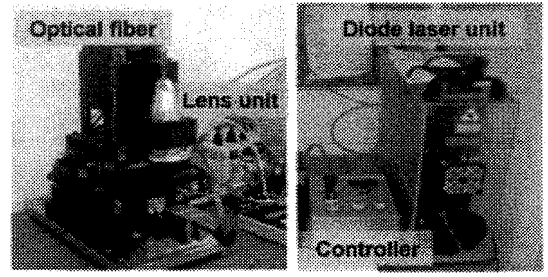

(b) Laser heat treatment system

Fig.1 Multi-functional micro machine tool

3 低出力半導体レーザによる薄板への焼入れ

\section{3-1 実跙方法}

試作機に搭載した半導体レーザを用いて，薄板に対して の焼入れ性を評価した. ワークとしては, $30 \times 30 \times 0.5[\mathrm{~mm}]$ の $\mathrm{S} 60 \mathrm{C}$ を使用した。条件としては，送り速度を $100,200,300,500,[\mathrm{~mm} / \mathrm{min}]$ で行った. 試料断面を研磨, 腐食 させ, 光学顕微鏡で観察し, レーザ照射断面の変質部の幅 と深さを測定した．また焼入れ性の板厚による影響を調べ るため同じ材質で板厚 $1.0,0.9,0.8,0.7,0.6[\mathrm{~mm}]$ の薄板につ いても同様に実験を行った。

\section{3-2 実䌞結果}

図 2 に送り $100 \mathrm{~mm} / \mathrm{min}$ でレーザ照射後の薄板（板厚 $0.5 \mathrm{~mm}$ ）の断面写真を示す.この条件では, 薄板の裏側ま で烇入れされていることがわかる．図３は，送り速度と焼 入れ深さおよび幅の関係を示したものである.これより送
り速度が遅い場合，レーザによる部分焼入れではなく全体 焼入れが可能であるということがわかる.ささらに図 4 に, 板厚と焼入れ深さおよび幅の関係を示す．これより板厚が 薄くなるに伴い, 焼入れ性が向上し, 板厚 $0.5 \mathrm{~mm}$ 以下のワ 一クであれは，裏側まで焼入れされる全体的な焼入れが可 能であるということがわかる.

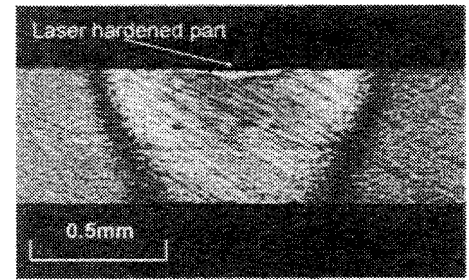

Fig.2 Cross section photograph of laser hardening

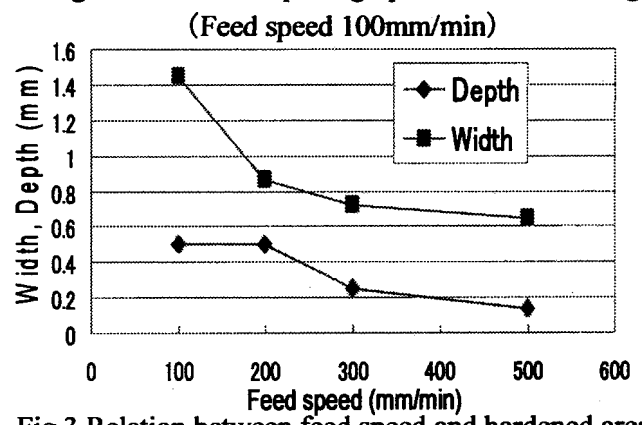

Fig.3 Relation between feed speed and hardened area

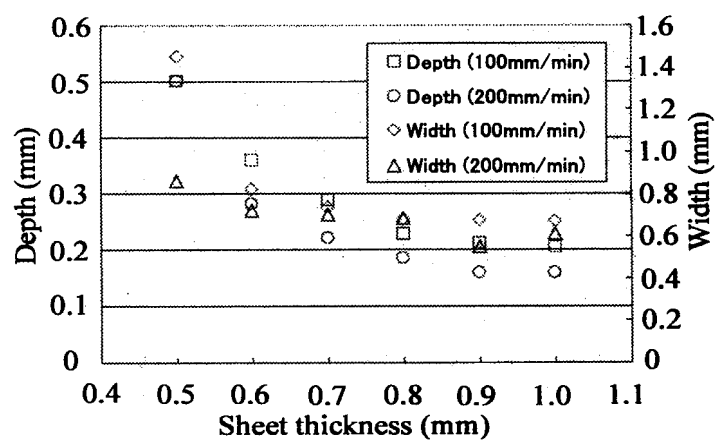

Fig.4 Relation between sheet thickness and hardened area 4 結 言

薄板へのレーザ焼入れの際, 送り速度の減少および板厚 が薄くなるにつれ，焼入れ性が向上し全体焼入れが可能に なる.

\section{謝辞}

本研究の遂行にあたり多大なご尽力を頂いた，俐岩間工 業所 岩間 正俊 氏, 株式会社セントラルエンジニアリン グ 久保 かおる 氏に厚く御礼申し上げます.

$$
\text { 参考文献 }
$$

1) Toshiki HIROGAKI, Eiichi AOYAMA, Keiji OGAWA, Takuya NISHIKUBO, Mikihito FUJIOKA, Masatoshi IWAMA, Kaoru KUBO : Development of Multi-functional Mini Machine Tool for Cell Manufacturing System, 2006 International Symposium on Flexible Automation 